\title{
Spatial particle size distribution at intact sample surfaces of a Dystric Cambisol under forest use
}

\author{
Steffen Beck-Broichsitter ${ }^{1 *}$, Marisa R. Gerriets ${ }^{2}$, Martin Neumann ${ }^{3}$, Jan-Frantisek Kubat ${ }^{3}$, \\ Jaromir Dusek ${ }^{1}$ \\ ${ }^{1}$ Department of Hydraulics and Hydrology, Faculty of Civil Engineering, Czech Technical University in Prague, Thakurova 7, 166 29, \\ Prague, Czech Republic. \\ ${ }^{2}$ Research Area 1 "Landscape Functioning", Leibniz Centre for Agricultural Landscape Research (ZALF), Eberswalder Straße 84, 15374 \\ Müncheberg, Germany. \\ ${ }^{3}$ Department of Landscape Water Conservation, Faculty of Civil Engineering, Czech Technical University in Prague, Thakurova 7, 16629, \\ Prague, Czech Republic. \\ * Corresponding author. E-mail: s.beck-broichsitter@soils.uni-kiel.de
}

\begin{abstract}
The idea of the present study is to describe the spatially varying particle size distribution (PSD) along intact aggregate surfaces with the laser diffraction method (LDM) of four silty-loamy and OC enriched horizons of a Dystric Cambisol from the Uhlirrská catchment (Czech Republic) with the laser diffraction method (LDM). Besides, the comparability of the LDM with the sieve and pipette method (SPM), the reproducibility, and the effect of pretreatment on the particle size distribution derived by LDM were analysed.

The laser diffraction method enables rapid and continuous particle size distribution measurements with required sample amounts of 0.1-0.2 g for each measurement compared to 5-20 g for SPM. The LDM-derived PSD's can be directly compared with the standardised SPM-derived PSD's by using regression analysis with coefficients of determination ( $\left.\mathrm{r}^{2}\right)$ between 0.83 and 0.93 . Sample pretreatment following standardised proceedings indicates a better comparability between the particle size distributions of both methods. Besides, the highest coefficients of variation of up to 78.6 and therefore the lowest reproducibility were found for the unpretreated PSD of the AE and Bs horizon. Thus, limited evaluability and reproducibility of soil material enriched in organic carbon (OC), used in the current study, needs further analysis.

For spatial analysis of PSD's along intact surfaces of soil aggregates and profiles, spatial data interpolation by inverse distance weighting (IDW), kriging, and triangulated irregular networks (TIN) can be used for detailed measuring, mapping, and spatial extension of the sand, silt, and clay fractions at unsampled locations using a set of samples of known locations. The information offers the possibility of comparing and verifying data obtained by non-invasive midinfrared spectroscopy and Vis-NIR spectroscopy by spatial extension for given soil aggregates and profiles.
\end{abstract}

Keywords: Laser diffraction method; Sieve and pipette method; Geoprocessing.

\section{INTRODUCTION}

In structured forest soils, root channels (Dohnal et al., 2012; Leue et al., 2020), shrinkage cracks, and differently sized stones and fragments (Dusek and Vogel, 2019) form multidimensional macropore networks. These macropores are of great importance for describing preferential flow and transport processes (Fér et al., 2016), and sorption behaviour (BeckBroichsitter et al., 2020a) in soils. The mass exchange between the macropore and soil matrix domains depends on the pore geometries (Leue et al., 2020), as well as volume and thickness of clay-organic coatings along macropore walls (BeckBroichsitter et al., 2020b). The spatial distribution of organic carbon (OC) (Leue et al., 2018), particle size distribution (Yang et al., 2019), clay minerals (Beck-Broichsitter et al., 2020a), and wettability (Beck-Broichsitter et al., 2020c; Fér et al., 2016) are also of major importance.

Intact soil aggregates from the same diagnostic horizon can be used to account for a similarity in the pore structure but can differ in OC and texture due to small-scale heterogeneity (Leue et al., 2020). For better description of PSD along heterogeneous structured soil surfaces, methods with lower material usage such as the laser diffraction method (Polakowski et al., 2021; Yang et al., 2019) are required. The reason is the limited amount of soil material that can be separated from thin macropore surfaces (Leue et al., 2017). Compared to the SPM, the LDM is less time consuming, and a smaller sample size is needed, and the possibility to use ultrasound to disperse soil aggregates is given (e.g., Bieganowski et al., 2018; Kubínová, 2021).

In this study, intact aggregate surfaces of soil horizons of the Dystric Cambisol from the Uhlírská catchment (Jizera Mountains, Czech Republic) were selected. This soil type is known for its heterogeneity and OC abundance of up to $80-100 \mathrm{~g} \mathrm{~kg}^{-1}$ in the topsoil layer (e.g., Sanda and Cislerova, 2009). This raises issues about soil sample pretreatment (i.e., Bieganowski et al., 2018; Jensen et al., 2017; Thomas et al., 2021), since bonding substances like OC and (iron)oxides can form microaggregates $(\leq 250 \mu \mathrm{m})$ (Mikutta et al., 2006), and thereby act as sand and silt fraction, while clay faction is underestimated (Zimmermann and Horn, 2020).

The idea of the present study is to describe the spatially varying particle size distributions along intact aggregate surfaces with the laser diffraction method of four silty-loamy and OC enriched horizons of a Dystric Cambisol from the Uhlírská catchment (Czech Republic) with the laser diffraction method. An additional focus is based on the comparability of the LDM with the standardised SPM, the reproducibility, and 
the effect of pretreatment of $\mathrm{OC}$ enriched soil material on the particle size distribution derived by LDM.

The authors hypothesise that LDM is an appropriate method for describing the spatially varying PSD's on intact aggregate surfaces. The information is useful for calibration and validation of non-invasive spectroscopy methods describing the PSD of differently structured soils on millimetre-to centimetre scales.

\section{MATERIAL AND METHODS 2.1 Study site}

The Uhlírská catchment $\left(15^{\circ} 18^{\prime} \mathrm{E}, 50^{\circ} 49^{\prime} \mathrm{N}\right)$ is located at the Jizera Mountains in northern Bohemia in the Czech Republic. The catchment is characterised by a mean annual temperature of $4.7{ }^{\circ} \mathrm{C}$ and a mean annual precipitation of $1380 \mathrm{~mm}$ (Sanda et al., 2014). The catchment was deforested between 1983 and 1985 and later reforested by spruce monoculture (Picea abies). The soil profiles along the hillslopes are relatively shallow $(<90 \mathrm{~cm})$ and can be classified as Dystric Cambisols and Podsols following IUSS Working Group WRB (2015), formed on the weathered and fractured granite bedrock (Sanda and Cislerova, 2009).

\subsection{Soil classification and characteristics}

Disturbed and undisturbed soil samples were collected from a Dystric Cambisol (Fig. 1) with $\mathrm{AE} / \mathrm{Bs} / \mathrm{Bsw} / \mathrm{BwC} / \mathrm{C}$ horizons (IUSS Working Group WRB, 2015). Disturbed soil samples were used to determine the soil physical and chemical properties. An Orion $2 \mathrm{Star} \mathrm{pH}$ meter was used to determine the $\mathrm{pH}$ values with a $\mathrm{pH}$-electrode (Thermo Scientific Fisher, Waltham, MA, USA) in a suspension containing $0.01 \mathrm{M} \mathrm{CaCl}_{2}$ solution (solid/liquid ratio 1:2.5). The OC content was calculated as difference between the total carbon content measured with the vario MICRO cube analyser (Elementar Analysensysteme GmbH, Langenselbold, Germany) and the inorganic carbon content determined with $10 \% \mathrm{HCl}$ by Scheibler method (Blume et al., 2011). Amorphous and crystalline iron fractions were measured by dithionitecitrate $\left(\mathrm{Fe}_{\mathrm{d}}\right)$ and ammonium oxalate $\left(\mathrm{Fe}_{\mathrm{ox}}\right)$ method (Mehra and Jackson, 1960).

\subsection{Soil pretreatment}

In the first step, disturbed material from each horizon was separated into a) $2000 \mu \mathrm{m}$-sieved soil without pretreatment and b) $2000 \mu \mathrm{m}$-sieved soil with pretreatment. Pretreatment for SPM was performed with 10-20 g of air-dried and sieved soil $(<2000 \mu \mathrm{m})$. Soil organic matter was removed with $30 \%$ peroxide in a water bath at around $70-80{ }^{\circ} \mathrm{C}$. Peroxide was added in several steps until no more gas was generated (ISO 11277:2020). Carbonates were removed by adding 10\% hydrochloric acid in several steps until $\mathrm{CO}_{2}$ release was no longer detectable (ISO 11277:2020). Iron oxides were reduced by adding $0.3 \mathrm{M}$ sodium citrate and $1 \mathrm{M}$ sodium hydrogen carbonate solution to the soil material. The suspension was heated in a water bath at around $70-80{ }^{\circ} \mathrm{C} .1 \mathrm{~g}$ of sodium dithionite was additionally added to the suspension and stirred for 30 minutes (ISO 11277:2020). In a last step, 0.5 M sodium monothiophosphate was added to the suspension right before shaking for around 2 hours with 180-200 rpm.

\subsection{Intact soil samples and pretreatment}

Small undisturbed samples with edge lengths between $3 \mathrm{~cm}$ and $5 \mathrm{~cm}$ were manually separated from larger soil blocks of 20 $\mathrm{cm}$ height and length cutted out from each of the four horizons of Dystric Cambisol. A stainless-steel frame with grid cells of $1.2 \mathrm{~cm}$ edge length was placed on the top of the sample and the size of the grid cells was tested and chosen to ensure the separation of sufficient soil material (approx. 0.5-2.5 g) for the PSD analysis, even after pretreatment (i.e., OC removal) using a scalpel (Leue et al., 2018, 2019).

Due to the smaller sample size, the pretreatment standards (ISO 11277:2020) were modified. Each sample was transferred into an own beaker standing in a water bath at around $70{ }^{\circ} \mathrm{C}$. $30 \%$ peroxide and later $10 \%$ hydrochloric acid were carefully and stepwise pipetted for around 7 days until no more gas was generated (ISO 11277:2020). After SOC and carbonate removal, the samples were dispersed in distilled water and refilled in new beaker standing in a heated water bath.

In a next step, iron oxides were reduced by stepwise pipetting $5 \mathrm{ml} 0.3 \mathrm{M}$ sodium citrate, few drops of $1 \mathrm{M}$ sodium hydrogen carbonate, and around $0.1 \mathrm{~g}$ of sodium dithionite to the solution and manually stirred. Few drops of sodium monothiophosphate were added to the suspensions right before refilling in tubes for shaking with a rotatory shaker for around 24 hours with $60 \mathrm{rpm}$.

In a last step, the suspensions were transferred into $20 \mathrm{ml}$ plastic centrifuge tubes and centrifuged for about 15 minutes for $5000 \mathrm{rpm}$ with a Thermo Scientific Heraeus Labofuge 300 centrifuge with 12 place rotor (Waltham, MA, USA). A pipette is then used for careful removal of the solution and the soil material is remaining in the tubes. During this removal, clay particles can accidently escape and thus, caution is advised here.

\subsection{Sieve and pipette method}

The standard technique determining the soil PSD is the combined sieve and pipette method (ISO 11277:2020). The sand fraction $(63-2000 \mu \mathrm{m})$ is separated from the silt $(63-2 \mu \mathrm{m})$ and clay fraction $(<2 \mu \mathrm{m})$ and the silt and clay fraction is determined by the sedimentation procedure using Köhn pipette for partition of both fractions by Stokes's law (Stokes, 1851) with 3 replications for each horizon, respectively. This widely adopted and cost-effective method describes the PSD as mass percentage of each size class. During the sedimentation, the Stokes' law relates the time settling of the particle sizes $<63 \mu \mathrm{m}$ (equivalent spherical diameter) remaining suspended in the solution (ISO 11277:2020). The sand, silt and clay contents were determined gravimetrically after drying at $105^{\circ} \mathrm{C}$ for 24 hours.

\subsection{Laser diffraction method}

The laser diffractometer Mastersizer 3000 (Malvern Panalytical Ltd, Malvern, UK) with Hydro EV dispersion unit was used to determine the PSD. The measurements were performed in degassed, distilled water dispersion and air trapped in the system was automatically removed before measurement. A small amount of water is then pipetted to the remaining soil in the tubes and manually stirred to receive a paste. Three replications of each sample set per horizon were dosed as paste into the Hydro EV dispersion unit and each replication (0.1-0.2 g) was automatically measured 25 times. The standard operation procedure for LDM measurements (stirrer speed, refractive index) were chosen based on former calibration experiments with soil material from Uhlírská catchment. The length of a

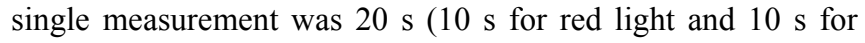
blue light) and the stirrer speed was $2050 \mathrm{rpm}$. The dispersion process is divided into a pre-ultrasound phase between the $1^{\text {st }}$ and $5^{\text {th }}$ measurement, the ultrasound phase between the $6^{\text {th }}$ and 
$19^{\text {th }}$ measurement, where the ultrasound at $100 \%$ power $(40 \mathrm{~W})$ was added, and the post-ultrasound phase between $20^{\text {th }}$ and $25^{\text {th }}$ measurement. A gradually decreasing particle size indicates dispersion and ultrasound will be applied until the particle size is no longer changing and the dispersion is stable (Mastersizer 3000 User Guide, 2020). The results show the mean and variance of the measurements with stable dispersion. The use of ultrasonication may cause dissolution, while the coarse fraction reduces in size and becomes more dominant as the fine material (Mastersizer 3000 User Guide, 2020).

Thus, the application of ultrasound may result in an overestimation of the clay fraction that needs to be tested in further projects.

The optical properties used during the measurements were a refractive index of 1.457 (soil, organic compounds: 1.4-1.7), an absorption index of 0.01 , and obscuration values varying between $8-15 \%$. The measurements were conducted in the measuring range of the device $(0.08-2100 \mu \mathrm{m})$. The properties were chosen after a range of preliminary studies finding the best operation procedure for the sample sets. The PSD's are classified according to the Soil Survey Staff (1999) with sand: 50-2000 $\mu \mathrm{m}$, silt: 50-2 $\mu \mathrm{m}$, and clay: $<2 \mu \mathrm{m}$ and Ad-Hoc-AG Boden (2005).

The post-processing data analysis was carried out with the Mastersizer 3000 software v3.62 (Malvern Panalytical Ltd, Malvern, UK) and the size distribution of the particles was calculated by Mie theory (Grehan et al., 1986) that has been found to be more accurate particularly for particles less than 50 $\mu \mathrm{m}$ in size (ISO 1332:2020-01). The PSD is described by a volume weighted mean considering the $10^{\text {th }}, 50^{\text {th }}$, and $90^{\text {th }}$ percentile (Malvern Panalytical Ltd, Malvern, UK).

\subsection{Analysis of spatial particle size distribution}

The soil samples from the four horizons were fixed on an aluminum plate and wrapped in tin-foil (Fig. 1). Photos of the samples with intact surfaces were georeferenced (EPSG: 25832, UTM zone 32N) using QGIS version 2.18.16 (QGIS Development Team, 2013). The same procedure was carried out with the reference grid ("fishnet") with $1.2 \mathrm{~cm} \times 1.2 \mathrm{~cm}$ cell size adjusted on the intact sample surface, respectively, corresponding to the PSD measurements (Fig. 1). The measured PSDderived sand, silt, and clay contents were joined with the numbered grid cells and interpolated for the intact sample surfaces using inverse distance weighting (IDW) algorithm with inverse distance potency of 2 in QGIS version 2.18.16 (QGIS Development Team, 2013). The IDW method was chosen based on experiences of Leue et al. (2018), because kriging assumes a homogenous variability of measured values (normal distribution of data) and outliers are strongly underestimated (e.g., Zarco-Perello and Simões, 2017).

\subsection{Statistical analysis}

The statistical software R ( R Development Core Team, 2021) was used to evaluate the sand, silt, clay contents obtained by LDM. Both data sets were normally distributed and heteroscedastic based on the results of graphical residue analysis and Shapiro-Wilk-Test. The statistical model for evaluating the data of dependent variables includes: a) sand, silt, and clay content, b) horizons (AE, Bs, Bsw, BwC), and c) their interaction terms (two-fold and three-fold). An analysis of variance (ANOVA) was than conducted with $\mathrm{p}<0.05$ followed by Tukey`s HSD test $\left({ }^{*} \mathrm{p} \leq 0.05, * * \mathrm{p} \leq 0.01, * * * \mathrm{p} \leq 0.001, * * * * \mathrm{p} \leq 0.0001\right)$ according to Hasler and Horton (2008). The R package 'The Soil Texture Wizard' was used to create texture plots (triangles).
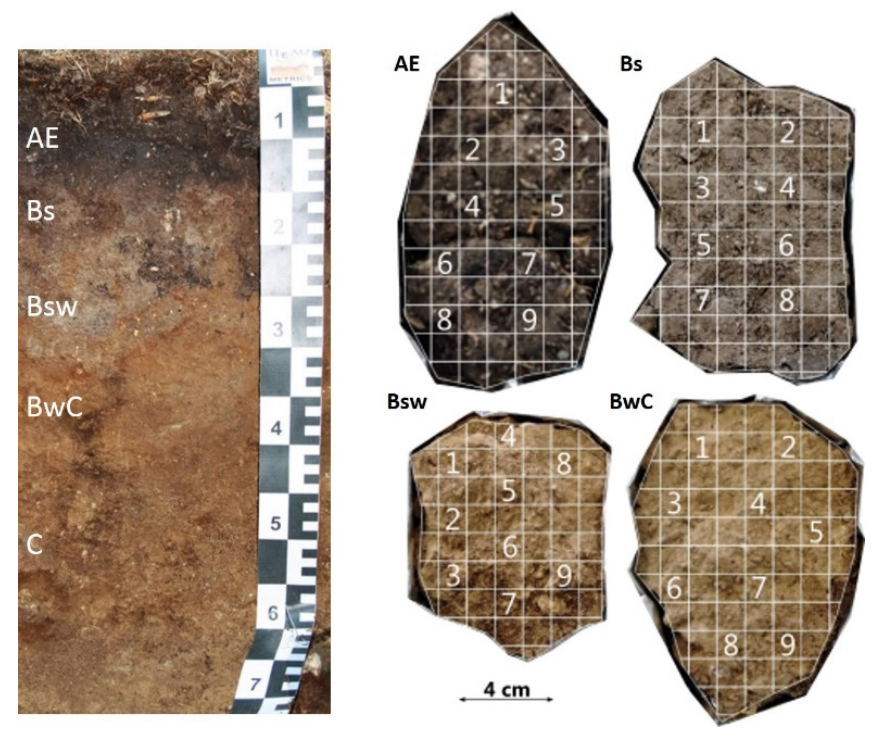

Fig. 1. Intact soil samples from hillslope loam-derived Dystric Cambisol with $\mathrm{AE} / \mathrm{Bs} / \mathrm{Bsw} / \mathrm{BwC} / \mathrm{C}$ horizons (left), located in the Jizera Mountains in northern Bohemia in the Czech Republic (Photo by M. Leue). Reference grid cells ("fishnet") with $1.2 \mathrm{~cm}$ edge length replace the stainless-steel frame and numbered grid cells mark the sampling points used in QGIS version 2.18.16 (QGIS Development Team, 2013) for $\mathrm{AE} / \mathrm{Bs} / \mathrm{Bsw} / \mathrm{BwC}$ horizons, respectively (right).

The reproducibility of LDM measurements was determined by the coefficient of variation (CV). As the ratio of the standard deviation to the average (\%), the lower the $\mathrm{CV}$ value, the higher is the reproducibility (e.g., Bieganowski et al., 2018; Polakowski et al., 2021).

\section{RESULTS AND DISCUSSION \\ 3.1 Impact of pretreatment on SPM and LDM}

The AE horizon shows the highest OC content with 83 $\mathrm{g} \mathrm{kg}^{-1}$, while the Bsw horizon shows the highest $\mathrm{pH}$ value with 4.2 and the highest contents in oxalate soluble iron, Feox, and dithionite soluble iron, $\mathrm{Fe}_{\mathrm{d}}$, with $24.9 \mathrm{~g} \mathrm{~kg}^{-1}$ and $30.1 \mathrm{~g} \mathrm{~kg}^{-1}$, respectively (Table 1).

The clay contents of the $\mathrm{Bs}, \mathrm{Bsw}$, and $\mathrm{BwC}$ horizons were tendentially higher after pretreatment of the samples. The Bs horizons also show a significant decrease in the sand content and an increase in the silt content for both classification systems (Table 2). The tendency of overestimating larger particles through particle aggregation ("pseudosand") and underestimating the fine fraction $<2 \mu \mathrm{m}$ in PSD of soils without prior pretreatment is underlined by findings of Zimmermann and Horn (2020), and Igaz et al. (2020).

Table 1. Soil properties of the $\mathrm{AE} / \mathrm{Bs} / \mathrm{Bsw} / \mathrm{BwC}$ horizons of the Dystric Cambisol (Fig. 1); OC content, $\mathrm{pHCaCl}^{2}$, oxalate, $\mathrm{Fe}_{\mathrm{ox}}$, and dithionite, $\mathrm{Fe}_{\mathrm{d}}$, soluble iron; mean values and standard deviations (symbol \pm ) of five repetitions each.

\begin{tabular}{llllll}
\hline Horizons & $\begin{array}{l}\text { Depth } \\
(\mathrm{cm})\end{array}$ & $\begin{array}{l}\mathrm{OC} \\
\left(\mathrm{g} \mathrm{kg}^{-1}\right)\end{array}$ & $\begin{array}{l}\mathrm{pH}_{\mathrm{CaCl} 2} \\
(-)\end{array}$ & $\begin{array}{l}\mathrm{Fe}_{\mathrm{ox}} \\
\left(\mathrm{g} \mathrm{kg}^{-1}\right)\end{array}$ & $\begin{array}{l}\mathrm{Fe}_{\mathrm{d}} \\
\left(\mathrm{g} \mathrm{kg}^{-1}\right)\end{array}$ \\
\hline $\mathrm{AE}$ & $0-10$ & $83 \pm 3$ & $4.0 \pm 0.3$ & $3.8 \pm 0.5$ & $6.9 \pm 0.2$ \\
$\mathrm{Bs}$ & $10-20$ & $47 \pm 9$ & $3.8 \pm 0.3$ & $17.8 \pm 0.4$ & $20.5 \pm 0.4$ \\
Bsw & $20-35$ & $56 \pm 4$ & $4.2 \pm 0.4$ & $24.9 \pm 0.4$ & $30.1 \pm 0.8$ \\
BwC & $35-50$ & $38 \pm 5$ & $4.2 \pm 0.3$ & $4.8 \pm 0.6$ & $9.3 \pm 0.4$ \\
\hline
\end{tabular}


In Table 2, the standard deviations and therefore the wide spread of the measured values for the sand and silt fraction of the Bs horizon need to be noted, while no significant differences between the measured unpretreated and pretreated PSD's were found for $\mathrm{AE}, \mathrm{Bsw}$, and BwC horizons. For explanation, the $\mathrm{AE}$ and $\mathrm{Bs}$ horizons can be mixed and are naturally very heterogenous. Thus, for example OC particles $<2000 \mu \mathrm{m}$ can also kit on the soil particles and will later swim on the top of the Hydro EV dispersion unit, negatively affecting the measurements. The use of ultrasonic may also cause dissolution, while the coarse fraction reduces in size and becomes more dominant as the fine material may resulting in a wider spread of the sand fraction (Table 2).

The texture plot on the left (Fig. 2) indicates a silty loam (SiLo) (Soil Survey Staff, 1999) and sandy silt (Us) (Ad-HocAG Boden, 2005) for the unpretreated and pretreated soil samples for the Bs, Bsw, and $\mathrm{BwC}$ horizons. The $\mathrm{AE}$ horizons shows a shift from loamy sand (LoSa) to sandy loam (SaLo) (Soil Survey Staff, 1999) or rather medium silty sand (Su3) (Ad-Hoc-AG Boden) after pretreatment (Fig. 2).
The pretreatment of the samples of the four horizons indicates a shift from a triple-peak structure towards a bi-peak structure of the PSD through smoothing the peak at around 300 $\mu \mathrm{m}$, while the peak around $1 \mu \mathrm{m}$ is steeper, except for the AE horizon (Fig. 3).

The highest average CV and therefore the lowest reproducibility for both classification systems were found for the sand, silt, and clay fraction of the Bs horizon and for the sand and clay fraction of pretreated samples of the Bsw and BwC horizons (Table 3). Thus, the lower the sand content (Table 2), the lower the reproducibility as also found by Polakowski et al. (2021). In our study, the texture classes of the four horizons are very limited (silty, sandy loam) and the previous statements is consistent for the present study.

It should be considered that the LDM itself is a repeatable method in contrast to SPM (e.g., Makó et al., 2019) and the reproducibility of the measurements depends on the texture (Goosens, 2008; Polakowski et al., 2021). Nevertheless, reproducible measurements require a clean, stable background, because particulate contaminations cause fluctuations on the background over time (Mastersizer 3000 User Guide, 2020).

Table 2. Unpretreated (up) and pretreated (p) particle size distribution (PSD) of the AE/Bs/Bsw/BwC horizons of a Dystric Cambisol determined by laser diffraction method (LDM) and classified according to Soil Survey Staff (1999) and Ad-Hoc-AG Boden (2005); mean values and standard deviations (symbol \pm ) of three repetitions each. Significant differences between unpretreated (up) and pretreated (p) sand, silt, and clay contents for each horizon and classification system are indicated by small asterisk $\left({ }^{*} \mathrm{p} \leq 0.05, * * \mathrm{p} \leq 0.01, * * * \mathrm{p} \leq 0.001\right.$, $* * * * \mathrm{p} \leq 0.0001)$.

\begin{tabular}{|c|c|c|c|c|c|c|c|c|}
\hline \multirow[b]{2}{*}{ Horizons } & \multirow[b]{2}{*}{$\begin{array}{l}\text { Depth } \\
(\mathrm{cm})\end{array}$} & & \multicolumn{3}{|c|}{ Soil Survey Staff (1999) } & \multicolumn{3}{|c|}{ Ad-Hoc-AG Boden (2005) } \\
\hline & & & $\begin{array}{l}\text { Sand } \\
(2000-50 \mu \mathrm{m})(\%)\end{array}$ & $\begin{array}{l}\text { Silt } \\
(50-2 \mu \mathrm{m})(\%)\end{array}$ & $\begin{array}{l}\text { Clay } \\
(<2 \mu \mathrm{m})(\%)\end{array}$ & $\begin{array}{l}\text { Sand } \\
(2000-63 \mu \mathrm{m})(\%)\end{array}$ & $\begin{array}{l}\text { Silt } \\
(63-2 \mu \mathrm{m})(\%)\end{array}$ & $\begin{array}{l}\text { Clay } \\
(<2 \mu \mathrm{m})(\%)\end{array}$ \\
\hline \multirow[t]{2}{*}{$\mathrm{AE}$} & $0-10$ & up & $72.6 \pm 14.8$ & $26.6 \pm 2.7$ & $0.6 \pm 0.1$ & $69.3 \pm 14.5$ & $30.0 \pm 3.1$ & $0.6 \pm 0.1$ \\
\hline & & $\mathrm{p}$ & $66.9 \pm 8.3$ & $32.0 \pm 5.0$ & $1.0 \pm 0.07$ & $63.7 \pm 8.2$ & $35.2 \pm 5.1$ & $1.0 \pm 0.07$ \\
\hline \multirow[t]{2}{*}{ Bs } & $10-20$ & up & $44.5 \pm 27.3^{*}$ & $52.9 \pm 22.0 * *$ & $2.5 \pm 1.9^{* *}$ & $40.7 \pm 26.5^{*}$ & $56.7 \pm 22.8^{*}$ & $2.5 \pm 1.9^{* *}$ \\
\hline & & $\mathrm{p}$ & $21.1 \pm 6.4^{*}$ & $72.9 \pm 5.4^{* *}$ & $5.9 \pm 0.9^{* *}$ & $18.2 \pm 6.3^{*}$ & $75.8 \pm 5.5^{*}$ & $5.9 \pm 0.9 * *$ \\
\hline \multirow[t]{2}{*}{ Bsw } & $20-35$ & up & $30.0 \pm 12.0$ & $67.3 \pm 10.2$ & $2.6 \pm 0.5$ & $26.0 \pm 11.7$ & $71.23 \pm 10.5^{*}$ & $2.6 \pm 0.5$ \\
\hline & & $\mathrm{p}$ & $35.0 \pm 17.8$ & $61.1 \pm 14.8$ & $3.8 \pm 1.9$ & $30.9 \pm 17.6$ & $65.2 \pm 15.1^{*}$ & $3.8 \pm 1.9$ \\
\hline \multirow[t]{2}{*}{$\mathrm{BwC}$} & $35-50$ & up & $37.3 \pm 5.3$ & $59.1 \pm 4.0$ & $3.5 \pm 1.2$ & $33.9 \pm 5.2$ & $62.5 \pm 4.1$ & $3.5 \pm 1.2$ \\
\hline & & $\mathrm{p}$ & $21.6 \pm 12.5$ & $73.3 \pm 8.3$ & $4.9 \pm 1.3$ & $19.0 \pm 11.4$ & $76.0 \pm 9.4$ & $4.9 \pm 1.3$ \\
\hline
\end{tabular}
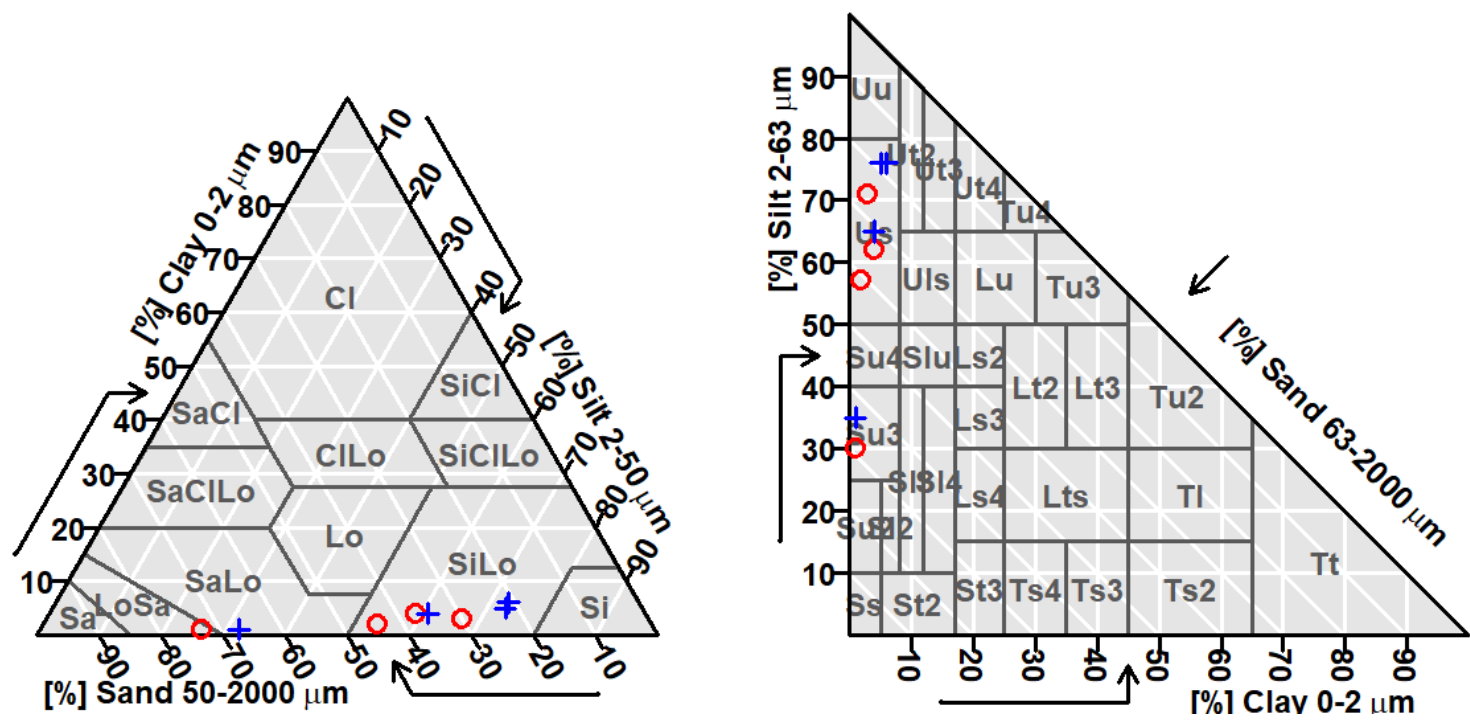

Fig. 2. Texture plots (triangles) of unpretreated (red dot) and pretreated (blue cross) samples of the $\mathrm{AE} / \mathrm{Bs} / \mathrm{Bsw} / \mathrm{BwC}$ horizons of a Dystric Cambisol determined by laser diffraction method (LDM) and classified according to Soil Survey Staff (1999) (left) and Ad-Hoc-AG Boden (2005) (right). 

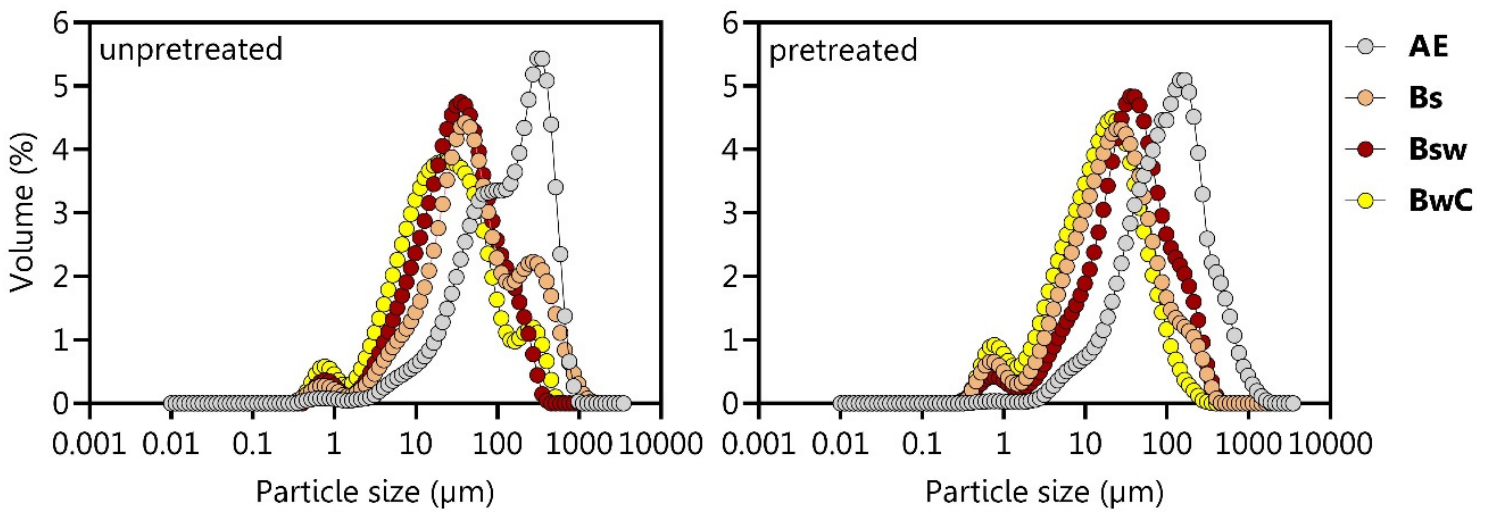

Fig. 3. Unpretreated (up) and pretreated (p) particle size distribution (PSD) of the $\mathrm{AE} / \mathrm{Bs} / \mathrm{Bsw} / \mathrm{BwC}$ horizons of a Dystric Cambisol determined by laser diffraction method (LDM); mean PSD of three repetitions each.

Table 3. Average coefficient of variation (CV) of unpretreated (up) and pretreated (p) particle size distribution (PSD) of the $\mathrm{AE} / \mathrm{Bs} / \mathrm{Bsw} / \mathrm{BwC}$ horizons of a Dystric Cambisol determined by laser diffraction method (LDM) and classified according to Soil Survey Staff (1999) and Ad-Hoc-AG Boden (2005); mean values of three repetitions each.

\begin{tabular}{|c|c|c|c|c|c|c|c|c|}
\hline \multirow[t]{2}{*}{ Horizons } & \multirow{2}{*}{$\begin{array}{l}\text { Depth } \\
\text { (cm) }\end{array}$} & & \multicolumn{3}{|c|}{ Soil Survey Staff (1999) } & \multicolumn{3}{|c|}{ Ad-Hoc-AG Boden (2005) } \\
\hline & & & $\begin{array}{l}\text { Sand } \\
(2000-50 \mu \mathrm{m}) \\
\text { CV }(\%)\end{array}$ & $\begin{array}{l}\text { Silt } \\
(50-2 \mu \mathrm{m}) \\
\text { CV }(\%)\end{array}$ & $\begin{array}{l}\text { Clay } \\
(<2 \mu \mathrm{m}) \\
\text { CV }(\%)\end{array}$ & $\begin{array}{l}\text { Sand } \\
(2000-63 \mu \mathrm{m}) \\
\text { CV }(\%)\end{array}$ & $\begin{array}{l}\text { Silt } \\
(63-2 \mu \mathrm{m}) \\
\text { CV }(\%)\end{array}$ & $\begin{array}{l}\text { Clay } \\
(<2 \mu \mathrm{m}) \\
\text { CV }(\%)\end{array}$ \\
\hline \multirow[t]{2}{*}{$\mathrm{AE}$} & $0-10$ & up & 20.3 & 10.4 & 18.8 & 20.9 & 10.2 & 18.8 \\
\hline & & $\mathrm{p}$ & 12.4 & 15.6 & 6.9 & 12.8 & 14.6 & 6.9 \\
\hline \multirow[t]{2}{*}{ Bs } & $10-20$ & up & 61.3 & 41.6 & 78.6 & 65.2 & 40.2 & 78.6 \\
\hline & & $\mathrm{p}$ & 30.3 & 7.4 & 15.6 & 34.7 & 7.2 & 15.6 \\
\hline \multirow[t]{2}{*}{ Bsw } & $20-35$ & up & 40.1 & 15.2 & 21.5 & 45.2 & 14.7 & 21.5 \\
\hline & & $\mathrm{p}$ & 50.9 & 24.3 & 51.7 & 56.9 & 23.1 & 51.7 \\
\hline \multirow[t]{2}{*}{$\mathrm{BwC}$} & $35-50$ & up & 14.2 & 6.8 & 35.2 & 15.5 & 6.5 & 35.3 \\
\hline & & $\mathrm{p}$ & 57.9 & 11.3 & 26.3 & 60.3 & 12.4 & 26.3 \\
\hline
\end{tabular}

Table 4. Pretreated (p) particle size distribution (PSD) of the $\mathrm{AE} / \mathrm{Bs} / \mathrm{Bsw} / \mathrm{BwC}$ horizons of a Dystric Cambisol determined by sieve and pipette method (SPM) and laser diffraction method (LDM) classified according to Ad-Hoc-AG Boden (2005); mean values and standard deviations (symbol \pm ) of three repetitions each. Significant differences between LDM- and SPM-derived sand, silt, and clay content for each horizon are indicated by small asterisks $\left({ }^{*} \mathrm{p} \leq 0.05, * * \mathrm{p} \leq 0.01, * * * \mathrm{p} \leq 0.001, * * * * \mathrm{p} \leq 0.0001\right)$.

\begin{tabular}{|c|c|c|c|c|c|c|c|c|}
\hline \multirow[t]{2}{*}{ Horizons } & \multirow{2}{*}{$\begin{array}{l}\text { Depth } \\
(\mathrm{cm})\end{array}$} & & \multicolumn{3}{|l|}{ LDM } & \multicolumn{3}{|l|}{ SPM } \\
\hline & & & $\begin{array}{l}\text { Sand } \\
(2000-63 \mu \mathrm{m}) \\
(\%)\end{array}$ & $\begin{array}{l}\text { Silt } \\
(63-2 \mu \mathrm{m}) \\
(\%)\end{array}$ & $\begin{array}{l}\text { Clay } \\
(<2 \mu \mathrm{m}) \\
(\%)\end{array}$ & $\begin{array}{l}\text { Sand } \\
(2000-63 \mu \mathrm{m}) \\
(\%)\end{array}$ & $\begin{array}{l}\text { Silt } \\
(63-2 \mu \mathrm{m}) \\
(\%)\end{array}$ & $\begin{array}{l}\text { Clay } \\
(<2 \mu \mathrm{m}) \\
(\%)\end{array}$ \\
\hline Bs & $10-20$ & $\mathrm{p}$ & $21.1 \pm 6.4$ & $72.9 \pm 5.4$ & $5.9 \pm 0.9$ & $34.4 \pm 16.4$ & $50.9 \pm 9.1$ & $14.6 \pm 7.3$ \\
\hline Bsw & $20-35$ & $\mathrm{p}$ & $35.0 \pm 17.8$ & $61.1 \pm 14.8$ & $3.8 \pm 1.9$ & $42.4 \pm 4.8$ & $51.4 \pm 9.8$ & $6.3 \pm 4.9$ \\
\hline BwC & $35-50$ & $\mathrm{p}$ & $21.6 \pm 12.5$ & $73.3 \pm 8.3$ & $4.9 \pm 1.3$ & $36.7 \pm 11.1$ & $56.3 \pm 16.8$ & $6.9 \pm 5.7$ \\
\hline
\end{tabular}

\subsection{Statistical comparison between SPM and LDM}

The results in Table 4 show no significant differences between the SPM- derived and LDM-derived sand, silt, and clay fraction, except for the clay fraction of the AE horizon. However, the sand and clay fraction tend to be higher in the SPM-derived PSD compared to the LDM-derived PSD, while the silt fraction shows an opposite trend, except for the $\mathrm{AE}$ horizon. The PSD's of each horizon primarily differ due to the different physical principle of SPM compared to LDM (Igaz et al., 2020). The position in the stirrer as part of the Hydro EV dispersion unit can also limit the reproducibility. A stirrer high above the bottom of the suspension-containing vessel is not efficient enough to move heavy particles (Polakowski et al., 2021). This circumstance would lead to an underestimation of the sand fraction. In opposite direction, a stirrer with highspeed at the bottom of the vessel would strongly push the larger sand fraction. Thus, the sand fraction would enter the measuring cell more often than it would appear from their fraction ratio (Polakowski et al., 2021) resulting in an underestimation of the fine fraction. Nevertheless, methodical errors cannot be excluded due to intermittent large standard deviations in Table 4. On the other side, both methods show widespread standard deviations and underline the difficulty in the measurement of PSD's of forest soils enriched in OC (Fér et al., 2016). Consequently, further analysis with soils enriched in OC and clay content are needed for better understanding of possibilities and limitations of LDM.

Based on finding of Makó et al. (2019), the upper limit of the clay fraction was increased from $2 \mu \mathrm{m}$ to $7 \mu \mathrm{m}$ for better comparability of PSD's derived by SPM and LDM (Table 5). The results in Table 5 show no significant differences between the SPM- derived and LDM-derived sand, silt, and clay fraction, even though the LDM-derived clay content is overestimated compared to the SPM, except for the AE horizon. Nevertheless, the upper limit of the clay content of $2 \mu \mathrm{m}$ will be kept for analysing the intact soil samples. 
Table 5. Pretreated (p) particle size distribution (PSD) of the AE/Bs/Bsw/BwC horizons of a Dystric Cambisol determined by sieve and pipette method (SPM) and laser diffraction method (LDM) classified according to Ad-Hoc-AG Boden (2005) with clay fraction $<7 \mu \mathrm{m}$ instead of $2 \mu \mathrm{m}$; mean values and standard deviations (symbol \pm ) of three repetitions each. Significant differences between LDM- and SPM-derived sand, silt, and clay content for each horizon, respectively, are indicated by small asterisk $\left({ }^{*} \mathrm{p} \leq 0.05,{ }^{* *} \mathrm{p} \leq 0.01,{ }^{* * *} \mathrm{p} \leq 0.001\right.$, $* * * * \mathrm{p} \leq 0.0001)$.

\begin{tabular}{lllllllll}
\hline Horizons & $\begin{array}{l}\text { Depth } \\
(\mathrm{cm})\end{array}$ & \multicolumn{2}{c}{ LDM } & \multicolumn{3}{c}{ SPM } \\
\cline { 3 - 8 } & & & $\begin{array}{l}\text { Sand } \\
(2000-63 \mu \mathrm{m})(\%)\end{array}$ & $\begin{array}{l}\text { Silt } \\
(63-7 \mu \mathrm{m})(\%)\end{array}$ & $\begin{array}{l}\text { Clay } \\
(<7 \mu \mathrm{m})(\%)\end{array}$ & $\begin{array}{l}\text { Sand } \\
(2000-63 \mu \mathrm{m})(\%)\end{array}$ & $\begin{array}{l}\text { Silt } \\
(63-2 \mu \mathrm{m})(\%)\end{array}$ & $\begin{array}{l}\text { Clay } \\
(<2 \mu \mathrm{m})(\%)\end{array}$ \\
\hline $\mathrm{AE}$ & $0-10$ & $\mathrm{p}$ & $66.9 \pm 8.3$ & $28.6 \pm 2.7$ & $4.5 \pm 1.8$ & $42.8 \pm 14.6$ & $43.8 \pm 10.3$ & $13.3 \pm 4.3$ \\
$\mathrm{Bs}$ & $10-20$ & $\mathrm{p}$ & $21.1 \pm 6.4$ & $59.1 \pm 4.2$ & $19.8 \pm 3.1$ & $34.4 \pm 16.4$ & $50.9 \pm 9.1$ & $14.6 \pm 7.3$ \\
$\mathrm{Bsw}$ & $20-35$ & $\mathrm{p}$ & $35.0 \pm 17.8$ & $53.2 \pm 6.2$ & $11.8 \pm 2.3$ & $42.4 \pm 4.8$ & $51.4 \pm 9.8$ & $6.3 \pm 4.9$ \\
$\mathrm{BwC}$ & $35-50$ & $\mathrm{p}$ & $21.6 \pm 12.5$ & $59.3 \pm 7.2$ & $19.1 \pm 2.6$ & $36.7 \pm 11.1$ & $56.3 \pm 16.8$ \\
\hline
\end{tabular}
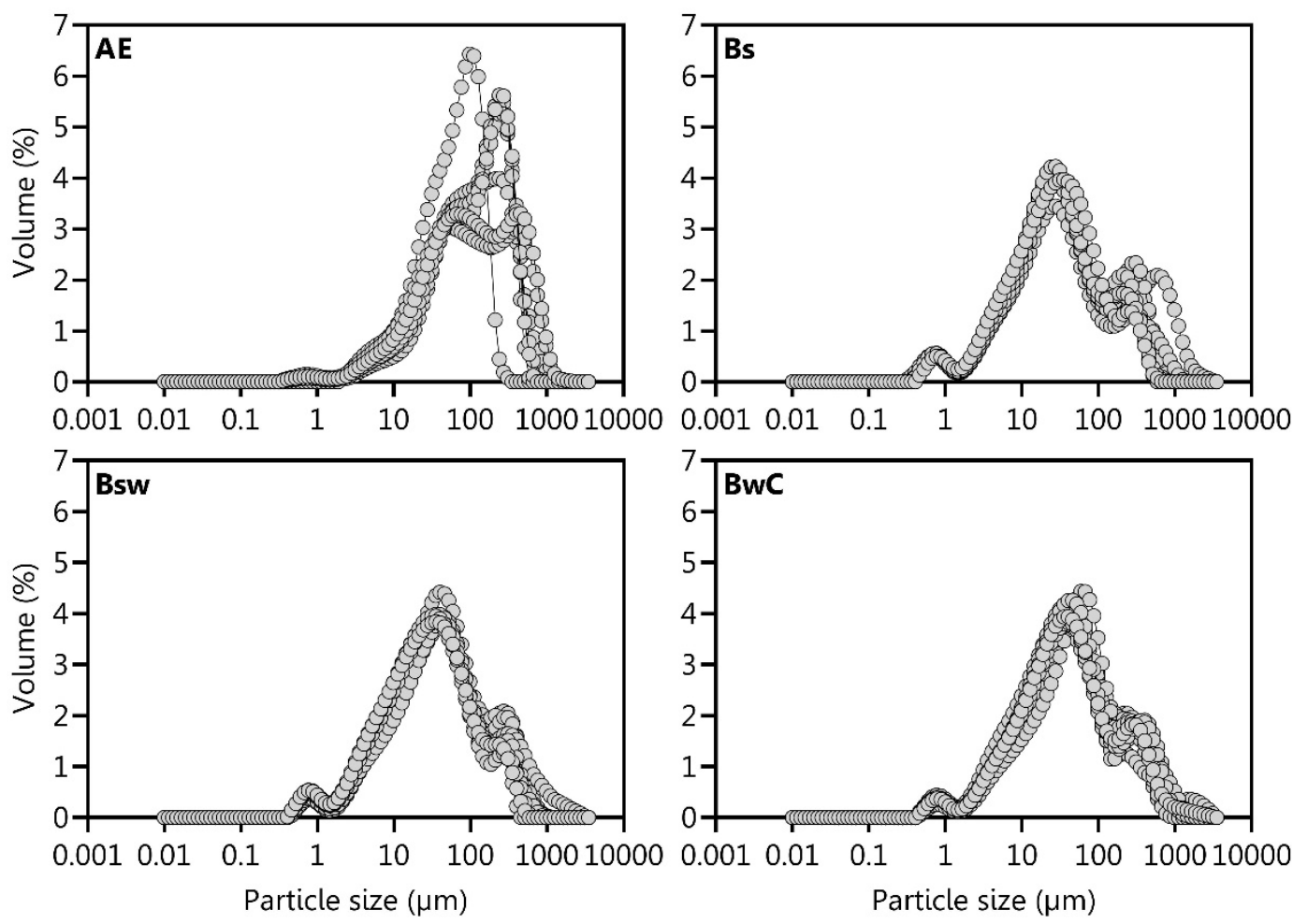

Fig. 4. Pretreated (p) particle size distribution (PSD) of the sampling points of intact soil samples from the AE/Bs/Bsw/BwC horizons of a Dystric Cambisol determined by laser diffraction method (LDM); mean PSD of three repetitions each.

The individual sampling points of the Bs, Bsw, and $\mathrm{BwC}$ horizons show a triple-peak structure with peaks at around 300 $\mu \mathrm{m}, 30 \mu \mathrm{m}$, and $1 \mu \mathrm{m}$ indicating the sand, silt, and clay fraction (Fig. 4). The sampling points along the sample surface of the AE horizon show a uni- and bimodal peak structure. The LDMderived PSD of the AE horizons indicates the comparatively highest sand fraction with $72.6 \%$ before and $66.9 \%$ after pretreatment (Table 2). Sand particles can easily stuck in the measurement cell of the Mastersizer (Malvern Panalytical Ltd, Malvern, UK), which is interface between the dispersion and the optical unit, causing an overestimation of the sand fraction (Mastersizer 3000 User Guide, 2020). Furthermore, an underestimation of the LDM-derived fine fraction as also found by Makó et al. (2019) can be attributed to the platy shape of clay particles being different than spherical (Bieganowski et al., 2018).

An intensive pretreatment procedure is needed for soils enriched in OC. Particle aggregation with OC before pretreatment can be stated as reason for a low LDM-derived clay content or rather an overestimated sand content (Igaz et al., 2020; Zimmermann and Horn, 2020). Study results of Vdović et al.
(2010) show that the presence of more than $1 \%$ organic matter may increase the aggregate stability, while affecting the LDMderived PSD's. In unpretreated soils, OC bound in stable and therefore enlarged aggregates can mime sand grains resulting in an overestimation of the sand fraction (Zimmermann and Horn, 2020). On the other hand, results of Koza et al. (2021) show no significant impact of chemical pretreatment on PSD's for organic-rich Chernozems and Kastanozem soils with average OC content of $29.5 \mathrm{~g} \mathrm{~kg}^{-1}$ and $16.3 \mathrm{~g} \mathrm{~kg}^{-1}$, respectively.

The small-scale heterogeneous distribution of forest soils mostly enriched in OC and its associated clay-organiccomplexation (Fér et al., 2016) mainly indicate the heterogenous distribution of clay along intact sample surfaces. Thus, an adequate removal of $\mathrm{OC}$, but also carbonates and iron compounds should be considered, even though there is no explicit focus on the effect of iron-organic-complexes or clay-organic complexes on LDM measurements in this study. These complexes can mime particles in the range of the sand fraction (Blume et al., 2011), while the clay fraction will be underestimated (Zimmermann and Horn, 2020). 
Table 6. Pretreated (p) particle size distribution (PSD) of the sampling points along intact surfaces of samples from the $\mathrm{AE} / \mathrm{Bs} / \mathrm{Bsw} / \mathrm{BwC}$ horizons of a Dystric Cambisol determined by laser diffraction method (LDM) and classified according to Soil Survey Staff (1999) and Ad-Hoc-AG Boden (2005). Significant differences between LDM-derived PSD`s in Table 4 and the sampling points of each horizon are indicated by small asterisks $(* \mathrm{p} \leq 0.05, * * \mathrm{p} \leq 0.01, * * * \mathrm{p} \leq 0.001, * * * \mathrm{p} \leq 0.0001)$.

\begin{tabular}{|c|c|c|c|c|c|c|c|}
\hline \multirow[t]{2}{*}{ Horizons } & \multirow{2}{*}{$\begin{array}{l}\text { Sampling } \\
\text { point }\end{array}$} & \multicolumn{3}{|c|}{ Soil Survey Staff (1999) } & \multicolumn{3}{|c|}{ Ad-Hoc-AG Boden (2005) } \\
\hline & & $\begin{array}{l}\text { Sand } \\
(2000-50 \mu \mathrm{m}) \\
(\%)\end{array}$ & $\begin{array}{l}\text { Silt } \\
(50-2 \mu \mathrm{m}) \\
(\%) \\
\end{array}$ & $\begin{array}{l}\text { Clay } \\
(<2 \mu \mathrm{m}) \\
(\%)\end{array}$ & $\begin{array}{l}\text { Sand } \\
(2000-63 \mu \mathrm{m}) \\
(\%)\end{array}$ & $\begin{array}{l}\text { Silt } \\
(63-2 \mu \mathrm{m}) \\
(\%) \\
\end{array}$ & $\begin{array}{l}\text { Clay } \\
(<2 \mu \mathrm{m}) \\
(\%)\end{array}$ \\
\hline \multirow[t]{8}{*}{$\mathrm{AE}$} & 1 & $67.3 \pm 4.1$ & $29.8 \pm 3.5$ & $2.8 \pm 2.7$ & $64.3 \pm 3.7$ & $32.8 \pm 3.9$ & $2.8 \pm 2.7$ \\
\hline & 2 & $69.9 \pm 5.9$ & $29.2 \pm 1.1$ & $0.7 \pm 0.0$ & $66.6 \pm 5.9$ & $32.5 \pm 1.1$ & $0.7 \pm 0.003$ \\
\hline & 3 & $71.2 \pm 9.7$ & $27.8 \pm 2.3$ & $0.8 \pm 0.0$ & $67.8 \pm 9.5$ & $31.2 \pm 2.5$ & $0.8 \pm 0.0$ \\
\hline & 4 & $64.9 \pm 12.5$ & $33.7 \pm 9.5$ & $1.2 \pm 1.3$ & $61.9 \pm 12.3$ & $36.7 \pm 9.7$ & $1.2 \pm 1.3$ \\
\hline & 5 & $68.8 \pm 4.1$ & $30.3 \pm 0.5$ & $0.7 \pm 0.0$ & $65.5 \pm 4.0$ & $33.7 \pm 0.5$ & $0.7 \pm 0.01$ \\
\hline & 6 & $66.5 \pm 15.6$ & $32.2 \pm 6.6$ & $0.7 \pm 0.0$ & $62.9 \pm 15.1$ & $35.8 \pm 7.2$ & $0.7 \pm 0.02$ \\
\hline & 7 & $54.7 \pm 11.5$ & $45.2 \pm 10.1$ & $0.01 \pm 0.01$ & $49.8 \pm 10.7$ & $50.1 \pm 10.9^{*}$ & $0.01 \pm 0.01$ \\
\hline & 8 & $74.1 \pm 19.8$ & $25.4 \pm 3.1$ & $0.4 \pm 0.1$ & $70.8 \pm 19.4$ & $28.7 \pm 3.5$ & $0.4 \pm 0.1$ \\
\hline \multirow[t]{8}{*}{ Bs } & 1 & $33.1 \pm 13.8$ & $63.1 \pm 10.9$ & $3.8 \pm 1.1$ & $30.3 \pm 13.5$ & $65.8 \pm 11.2$ & $3.8 \pm 1.1$ \\
\hline & 2 & $30.2 \pm 13.9$ & $65.3 \pm 11.3$ & $4.4 \pm 1.3$ & $27.5 \pm 13.8$ & $68.1 \pm 11.4$ & $4.4 \pm 1.3$ \\
\hline & 3 & $30.7 \pm 10.3$ & $64.5 \pm 8.1$ & $4.7 \pm 1.1$ & $28.1 \pm 10.2$ & $67.2 \pm 8.3$ & $4.7 \pm 1.1$ \\
\hline & 4 & $37.1 \pm 13.2$ & $59.1 \pm 10.4$ & $3.8 \pm 1.4$ & $34.5 \pm 13.1$ & $61.5 \pm 10.5$ & $3.8 \pm 1.4$ \\
\hline & 5 & $33.5 \pm 16.1$ & $62.2 \pm 13.7$ & $4.1 \pm 1.8$ & $30.7 \pm 16.1$ & $65.1 \pm 13.8$ & $4.1 \pm 1.8$ \\
\hline & 6 & $34.3 \pm 12.8$ & $61.9 \pm 10.6$ & $3.7 \pm 1.1$ & $31.8 \pm 12.6$ & $64.4 \pm 10.8$ & $3.7 \pm 1.1$ \\
\hline & 7 & $29.2 \pm 9.2$ & $65.9 \pm 7.7$ & $4.7 \pm 1.2$ & $26.5 \pm 9.2$ & $68.6 \pm 7.7$ & $4.7 \pm 1.2$ \\
\hline & 8 & $38.5 \pm 26.3$ & $56.3 \pm 19.1$ & $5.1 \pm 3.2$ & $36.2 \pm 26.0$ & $58.6 \pm 19.4$ & $5.1 \pm 3.2$ \\
\hline \multirow[t]{9}{*}{ Bsw } & 1 & $29.3 \pm 3.4$ & $66.2 \pm 2.6$ & $4.4 \pm 0.5 * * *$ & $25.9 \pm 3.4$ & $69.6 \pm 2.6$ & $4.4 \pm 0.5 * * *$ \\
\hline & 2 & $27.8 \pm 1.5$ & $67.5 \pm 1.4$ & $4.5 \pm 0.2 * * * *$ & $24.4 \pm 1.5$ & $70.9 \pm 1.5$ & $4.5 \pm 0.2 * * * *$ \\
\hline & 3 & $29.1 \pm 5.1$ & $66.7 \pm 4.5$ & $4.2 \pm 0.8^{* * *}$ & $25.7 \pm 4.9$ & $70.1 \pm 4.6$ & $4.2 \pm 0.8^{* * *}$ \\
\hline & 4 & $31.1 \pm 18.0$ & $64.9 \pm 7.3$ & $3.9 \pm 0.1 * *$ & $27.5 \pm 16.6$ & $68.5 \pm 8.6$ & $3.9 \pm 0.1 * *$ \\
\hline & 5 & $41.1 \pm 6.9$ & $55.6 \pm 2.8$ & $3.0 \pm 0.1$ & $37.4 \pm 6.6$ & $59.2 \pm 3.1$ & $3.1 \pm 0.1$ \\
\hline & 6 & $38.3 \pm 2.9$ & $58.4 \pm 0.4$ & $3.1 \pm 0.1$ & $34.6 \pm 2.9$ & $62.1 \pm 0.4$ & $3.1 \pm 0.1$ \\
\hline & 7 & $34.8 \pm 0.5$ & $61.9 \pm 0.3$ & $3.1 \pm 0.1$ & $30.7 \pm 0.4$ & $66.1 \pm 0.4$ & $3.1 \pm 0.1$ \\
\hline & 8 & $37.6 \pm 22.1$ & $59.3 \pm 7.6$ & $3.1 \pm 0.1$ & $34.1 \pm 20.5$ & $62.8 \pm 9.2$ & $3.0 \pm 0.1$ \\
\hline & 9 & $40.5 \pm 23.2$ & $56.5 \pm 9.4$ & $2.9 \pm 0.1$ & $37.3 \pm 21.5$ & $59.7 \pm 11.1$ & $2.9 \pm 0.1$ \\
\hline \multirow[t]{9}{*}{$\mathrm{BwC}$} & 1 & $38.0 \pm 2.4$ & $58.9 \pm 0.5$ & $2.8 \pm 0.2 * * *$ & $34.4 \pm 2.3$ & $62.5 \pm 0.6$ & $2.8 \pm 0.2 * * *$ \\
\hline & 2 & $33.2 \pm 3.4$ & $60.3 \pm 0.9$ & $3.2 \pm 0.1 * *$ & $29.9 \pm 3.2$ & $63.5 \pm 1.0$ & $3 . \pm 0.03 * *$ \\
\hline & 3 & $36.1 \pm 2.3$ & $61.0 \pm 0.8$ & $2.7 \pm 0.0 * * *$ & $32.1 \pm 2.3$ & $65.1 \pm 0.9$ & $2.7 \pm 0.02 * * *$ \\
\hline & 4 & $39.6 \pm 3.7$ & $57.2 \pm 0.7 *$ & $3.1 \pm 0.1 * *$ & $36.1 \pm 3.5$ & $60.7 \pm 0.9$ & $3.1 \pm 0.05 * *$ \\
\hline & 5 & $36.8 \pm 20.8$ & $59.9 \pm 8.7$ & $3.1 \pm 0.2 * *$ & $33.6 \pm 19.3$ & $63.2 \pm 10.2$ & $3.1 \pm 0.1 * *$ \\
\hline & 6 & $32.4 \pm 12.5$ & $64.0 \pm 5.6$ & $3.5 \pm 0.6^{*}$ & $28.9 \pm 12.2$ & $67.4 \pm 5.9$ & $3.5 \pm 0.6^{*}$ \\
\hline & 7 & $41.3 \pm 6.1$ & $55.2 \pm 3.6^{*}$ & $3.4 \pm 0.7 *$ & $37.6 \pm 6.1$ & $58.8 \pm 3.7^{*}$ & $3.4 \pm 0.7^{*}$ \\
\hline & 8 & $35.2 \pm 24.1$ & $61.1 \pm 9.7$ & $3.2 \pm 0.2 * *$ & $31.7 \pm 22.6$ & $64.7 \pm 11.2$ & $3.2 \pm 0.3 * *$ \\
\hline & 9 & $42.0 \pm 24.0$ & $55.3 \pm 12.2 *$ & $2.6 \pm 0.2 * * *$ & $38.0 \pm 22.1$ & $59.3 \pm 11.2$ & $2.6 \pm 0.2^{* * *}$ \\
\hline
\end{tabular}

The differences between the SPM-derived and LDM-derived PSD's in Table 4 require 2nd order polynomial regression analysis (Eqs. (1-3)) for improving the validity of the LDM compared to the laboratory reference standard in form of the SPM. While using 2nd order polynomial regression functions for determining the sand, silt, and clay fraction, respectively. If the fraction properties are in sum lower than $100 \%$, they need to be transformed or rather weighted to reach in sum $100 \%$ as provided by McNeill et al. (2018). Therefore, a proportional weighting factor (p) was implemented in Eq. (4) to weight the sand, silt, and clay fractions appropriate to its fraction proportions after using the regression functions:

Sand $(\%)_{\mathrm{SPM}}=$

$=-0.022 * \operatorname{Sand}(\%)_{\mathrm{LDM}^{2}}+2.10 * \operatorname{Sand}(\%)_{\mathrm{LDM}}+2.22$

Silt $(\%)_{\mathrm{SPM}}=$

$=0.021 * \operatorname{Silt}(\%)_{\mathrm{LDM}^{2}}-1.70 * \operatorname{Silt}(\%)_{\mathrm{LDM}}+55.36$
Clay $(\%)_{\mathrm{SPM}}=$

$=1.016 *$ Clay $(\%)_{\mathrm{LDM}^{2}}{ }^{2}-5.08 *$ Clay $(\%) \mathrm{LDM}+7.77$

$\mathrm{PSD}=\mathrm{pSand}(\%)_{\mathrm{SPM}}+\mathrm{pSilt}(\%)_{\mathrm{SPM}}+\mathrm{pClay}(\%)_{\mathrm{SPM}}$

where $\mathrm{p}$ is the proportional weighting factor using the percentage distribution of sand, silt, and clay derived from Eqs. (1-3).

The results of the $2^{\text {nd }}$ order polynomial regression analysis in Fig. 5 show coefficients of determination for polynomial regression analysis with $\mathrm{r}^{2}=0.88$ for sand, $\mathrm{r}^{2}=0.83$ for silt, and $\mathrm{r}^{2}=0.93$ for clay and for linear regression analysis with $\mathrm{r}^{2}=$ 0.73 for sand, $\mathrm{r}^{2}=0.77$ for silt, and $\mathrm{r}^{2}=0.79$ for clay.

Compared to studies with larger sample sets (e.g., Makó et al., 2019), the results in Fig. 5 based on a small sample set show the highest $\mathrm{r}^{2}$ for the polynomial regression analysis in contrast to the linear regression analysis. Further analysis with a larger sample set is needed to validate or negate the results of the polynomial regression analysis. 
However, the LDM-derived sand, silt, and clay contents from the AE-horizon were excluded from the regression analysis because of its reduced validity (linear and non-linear: sand: $r^{2}<0.45$, silt: $r^{2}<0.39$, clay: $\left.r^{2}<0.07\right)$, data not shown. Despite the intense pretreatment of the soil samples from the AE horizon, especially the clay content was strongly underestimated compared to SPM-derived PDS's. One critical point is the OC content of $>0.8 \mathrm{~g} \mathrm{~kg}^{-1}$ soil compared to the maximum threshold value of $0.2 \mathrm{~g} \mathrm{~kg}^{-1}$ soil (Jensen et al., 2017) that may increase the aggregate stability (de Oliveira et al., 2020) and lead to a dramatic underestimation of the fine fraction $(<2 \mu \mathrm{m})$.

SPM-based round robin tests all around Europe have shown that the laboratory staff is affecting the PSD's due to possible errors in sieving, pretreatment, and Köhn pipetting (data not published). Thus, careful soil preparation and especially pretreatment is necessary for both methods handling soils enriched in OC. Otherwise, the method comparison is biased. Further studies are also needed to systematically quantify the impact of other possible factors such as clay mineralogy and refractive index on LDM-derived PSDs (Yang et al., 2019). It should be noted that the pretreatment of smaller sample sizes is more difficult and time-consuming following the standards (ISO 11277:2020).

The proportional weighting factors (p) in Table 7 are necessary to sum up the regression analysis-based sand, silt, and clay fractions to $100 \%$. This happened appropriate to its regression analysis-based fraction proportions and the silt fraction shows the highest p-values compared to sand and clay.

\subsection{Spatial interpolation of particle size distribution}

The results in Fig. 6-9 show the spatial distribution of sand, silt, and clay fraction after $2^{\text {nd }}$ order polynomial regression analysis of the sampling points along the intact surfaces of the $\mathrm{AE}, \mathrm{Bs}, \mathrm{Bsw}$, and BwC horizons of the Dystric Cambisol using the IDW-algorithm in QGIs version 2.18.16. The results indicate an increase in the sand and clay fraction after $2^{\text {nd }}$ order polynomial regression analysis for all horizons, while the silt fraction decreased, respectively.

The comparison between IDW and kriging, a popular, but more complex methodology (Zarco-Perello and Simões, 2017), and considering experiences of Leue et al. (2018) in spatial interpolation along intact aggregate surfaces, allowed to choose the IDW in the current study. In addition, IDW is easier to define and therefore easier to understand the results ( $\mathrm{Li}$ and Heap, 2011).

An effective grid-based mapping of the PSD's along intact soil samples is possible, because the LDM-analysis only requires $0.5-2.5 \mathrm{~g}$ air-dried soil material compared to the 5-20 g air-dried soil that is needed for a sufficient SPM-analysis (e.g., Zimmermann and Horn, 2020). The LDM enables a rapid analysis and more detailed and continuous PSD measurements compared to sedimentation methods (Yang et al., 2019). This is important, because soils with similar fractions in sand, silt, and clay may have contrasting PSD's (Merkus, 2009). Nevertheless, the limited evaluability of soil material enriched in OC (AE horizon in the current study) needs further analysis.
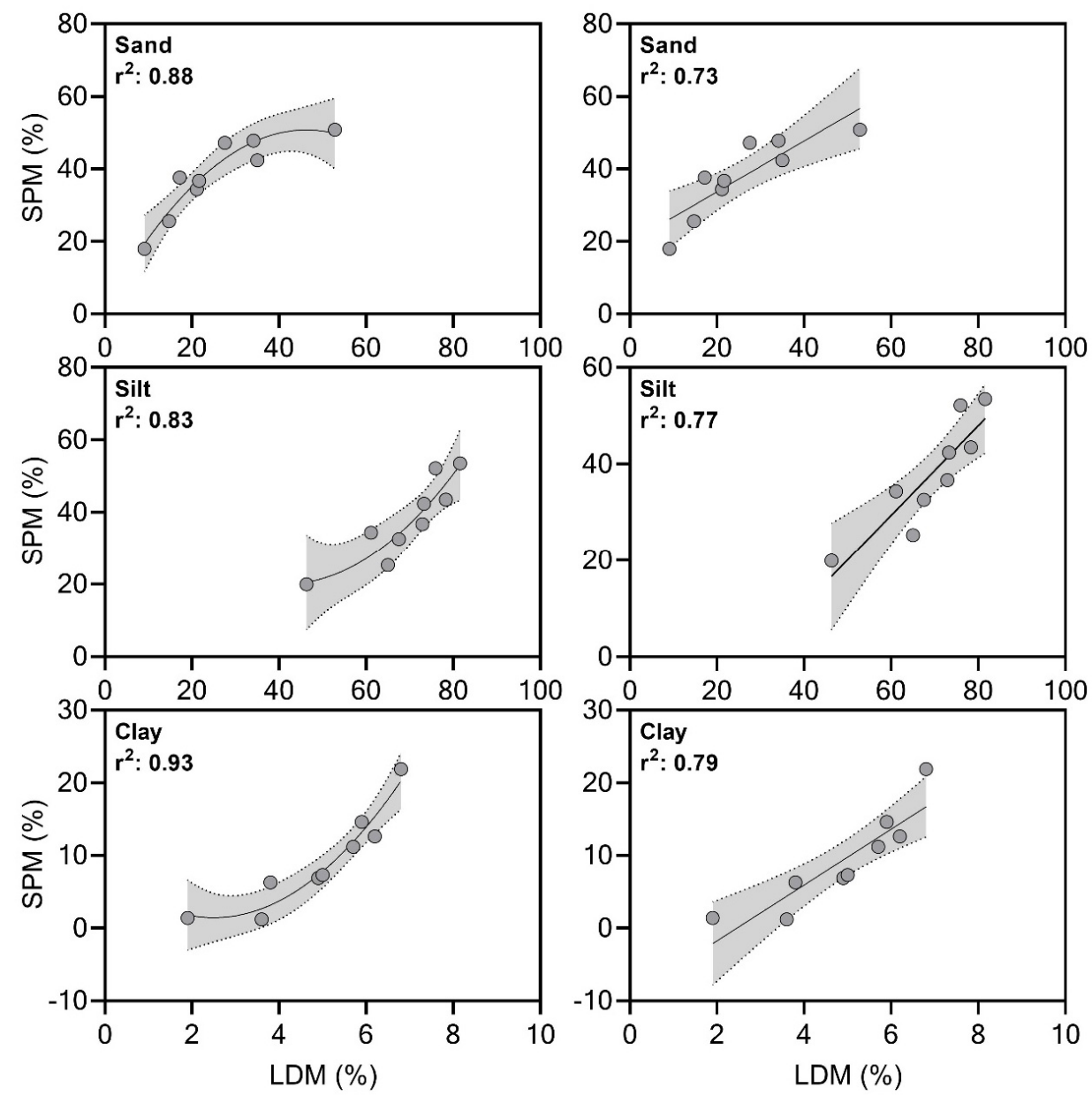

Fig. 5. Linear and $2^{\text {nd }}$ order polynomial regression analysis of the measured LDM-derived and SPM-derived sand $(630-2000 \mu \mathrm{m})$, silt $(630-2 \mu \mathrm{m})$, and clay $(<2 \mu \mathrm{m})$ contents from the Bs/Bsw/BwC horizons of a Dystric Cambisol. The symbols indicate the experimental data and the dashed lines the fitted data with error bars (standard deviation) for three repetitions each. The LDM-derived sand, silt, and clay contents of the AE-horizon were excluded from the regression analysis. 
Table 7. Proportional weighting factors ( $\mathrm{p}$ ) of the sampling points along intact surfaces of the samples from the $\mathrm{AE} / \mathrm{Bs} / \mathrm{Bsw} / \mathrm{BwC}$ horizons of a Dystric Cambisol based on the regression analysis (Eqs. (1-3)) for comparing LDM- and SPM-derived sand (630-2000 $\mu \mathrm{m})$, silt (630$2 \mu \mathrm{m})$, and clay $(<2 \mu \mathrm{m})$ content according to Ad-Hoc-AG Boden (2005).

\begin{tabular}{|c|c|c|c|c|c|c|c|c|c|c|c|c|}
\hline Horizons & & $\mathrm{AE}$ & & & Bs & & & Bsw & & & $\mathrm{BwC}$ & \\
\hline $\begin{array}{l}\text { Samp- } \\
\text { ling } \\
\text { point }\end{array}$ & $\begin{array}{l}\text { Sand } \\
(2000- \\
63 \mu \mathrm{m}) \\
\mathrm{p}(-)\end{array}$ & $\begin{array}{c}\text { Silt } \\
(63- \\
2 \mu \mathrm{m}) \\
\mathrm{p}(-)\end{array}$ & $\begin{array}{c}\text { Clay } \\
(<2 \mu \mathrm{m}) \\
\mathrm{p}(-)\end{array}$ & $\begin{array}{l}\text { Sand } \\
(2000- \\
63 \mu \mathrm{m}) \\
\mathrm{p}(-)\end{array}$ & $\begin{array}{c}\text { Silt } \\
(63- \\
2 \mu \mathrm{m}) \\
\mathrm{p}(-)\end{array}$ & $\begin{array}{c}\text { Clay } \\
(<2 \mu \mathrm{m}) \\
\mathrm{p}(-)\end{array}$ & $\begin{array}{l}\text { Sand } \\
(2000- \\
63 \mu \mathrm{m}) \\
\mathrm{p}(-)\end{array}$ & $\begin{array}{c}\text { Silt } \\
(63-2 \mu \mathrm{m}) \\
\mathrm{p}(-)\end{array}$ & $\begin{array}{c}\text { Clay } \\
(<2 \mu \mathrm{m}) \\
\mathrm{p}(-)\end{array}$ & $\begin{array}{l}\text { Sand } \\
(2000- \\
63 \mu \mathrm{m}) \\
\mathrm{p}(-)\end{array}$ & $\begin{array}{c}\text { Silt } \\
(63-2 \mu \mathrm{m}) \\
\mathrm{p}(-)\end{array}$ & $\begin{array}{c}\text { Clay } \\
(<2 \mu \mathrm{m}) \\
\text { p }(-)\end{array}$ \\
\hline 1 & 1.49 & 1.51 & 1.61 & 1.13 & 1.4 & 1.23 & 1.1 & 1.33 & 1.14 & 1.17 & 1.35 & 1.37 \\
\hline 2 & 1.52 & 1.49 & 1.06 & 1.11 & 1.34 & 1.15 & 1.1 & 1.31 & 1.13 & 1.15 & 1.34 & 1.34 \\
\hline 3 & 1.56 & 1.47 & 1.07 & 1.1 & 1.33 & 1.12 & 1.11 & 1.33 & 1.16 & 1.16 & 1.36 & 1.37 \\
\hline 4 & 1.43 & 1.56 & 1.14 & 1.15 & 1.45 & 1.25 & 1.12 & 1.36 & 1.2 & 1.17 & 1.35 & 1.34 \\
\hline 5 & 1.49 & 1.50 & 1.05 & 1.12 & 1.39 & 1.18 & 1.17 & 1.51 & 1.4 & 1.15 & 1.54 & 1.38 \\
\hline 6 & 1.43 & 1.52 & 1.05 & 1.13 & 1.42 & 1.25 & 1.15 & 1.46 & 1.36 & 1.12 & 1.49 & 1.28 \\
\hline 7 & 1.19 & 1.47 & 1.01 & 1.1 & 1.31 & 1.11 & 1.13 & 1.41 & 1.33 & 1.16 & 1.36 & 1.29 \\
\hline 8 & 1.64 & 1.412 & 1.02 & 1.13 & 1.39 & 1.1 & 1.15 & 1.46 & 1.37 & 1.14 & 1.47 & 1.34 \\
\hline 9 & - & - & - & - & - & - & 1.17 & 1.5 & 1.41 & 1.17 & 1.5 & 1.41 \\
\hline
\end{tabular}
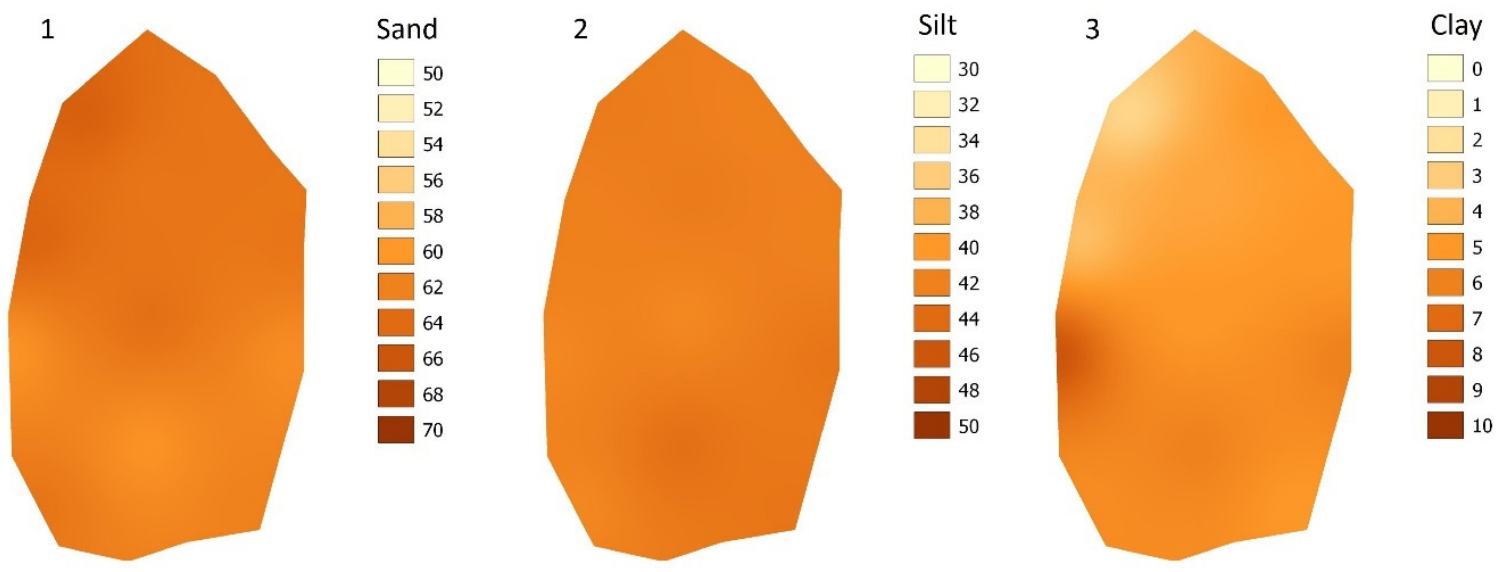

$$
4 \mathrm{~cm}
$$

Fig. 6. Spatial distribution (\%) of sand (630-2000 $\mu \mathrm{m})$, silt $(630-2 \mu \mathrm{m})$, and clay $(<2 \mu \mathrm{m})$ content according to Ad-Hoc-AG Boden $(2005)$ after $2^{\text {nd }}$ order polynomial regression analysis of the sampling points along intact surfaces from AE horizon of a Dystric Cambisol determined by laser diffraction method (LDM) using the inverse distance weighting (IDW) algorithm in QGIS version 2.18.16 (QGIS Development Team, 2013).

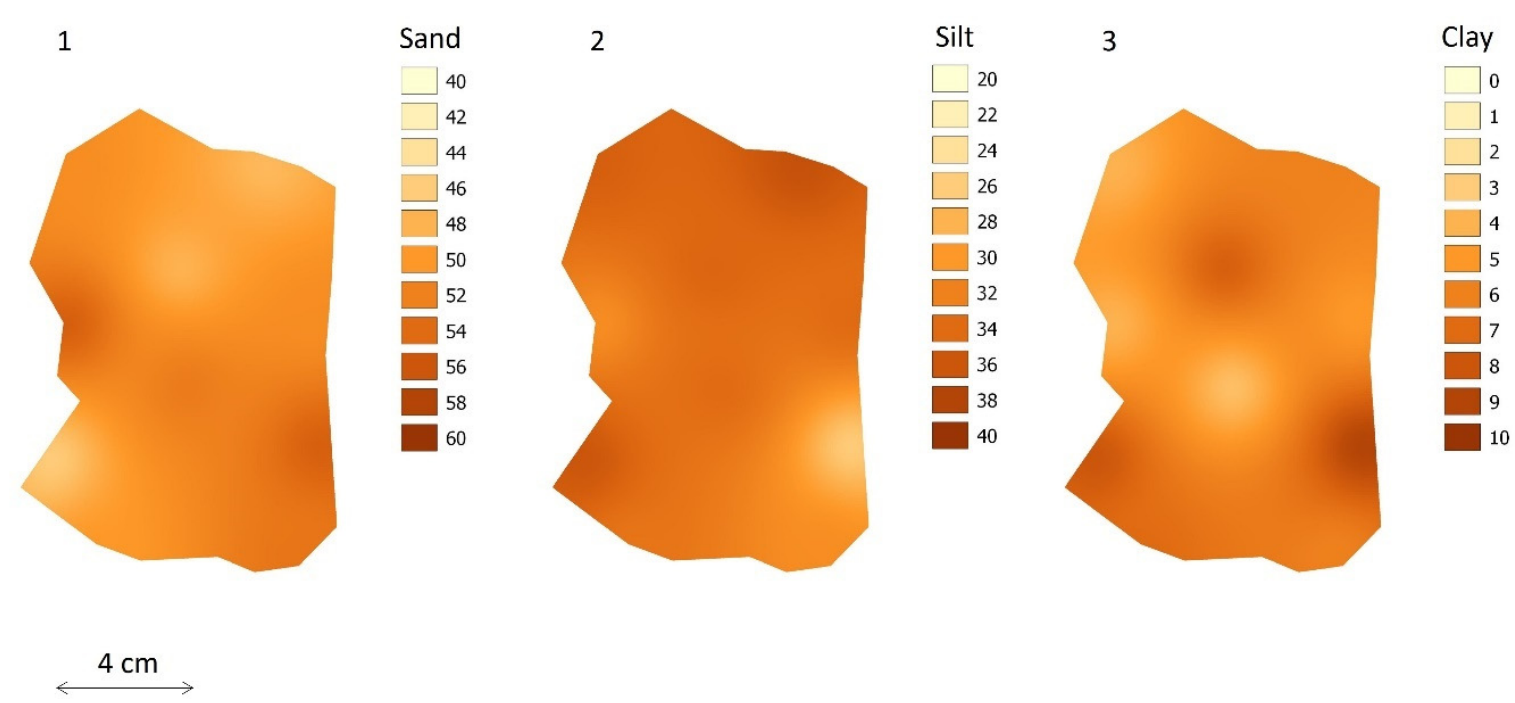

Fig. 7. Spatial distribution (\%) of sand $(630-2000 \mu \mathrm{m})$, silt $(630-2 \mu \mathrm{m})$, and clay $(<2 \mu \mathrm{m})$ content according to Ad-Hoc-AG Boden $(2005)$ after $2^{\text {nd }}$ order polynomial regression analysis of the sampling points along intact surfaces from Bs horizon of a Dystric Cambisol determined by laser diffraction method (LDM) using the inverse distance weighting (IDW) algorithm in QGIS version 2.18.16 (QGIS Development Team, 2013). 

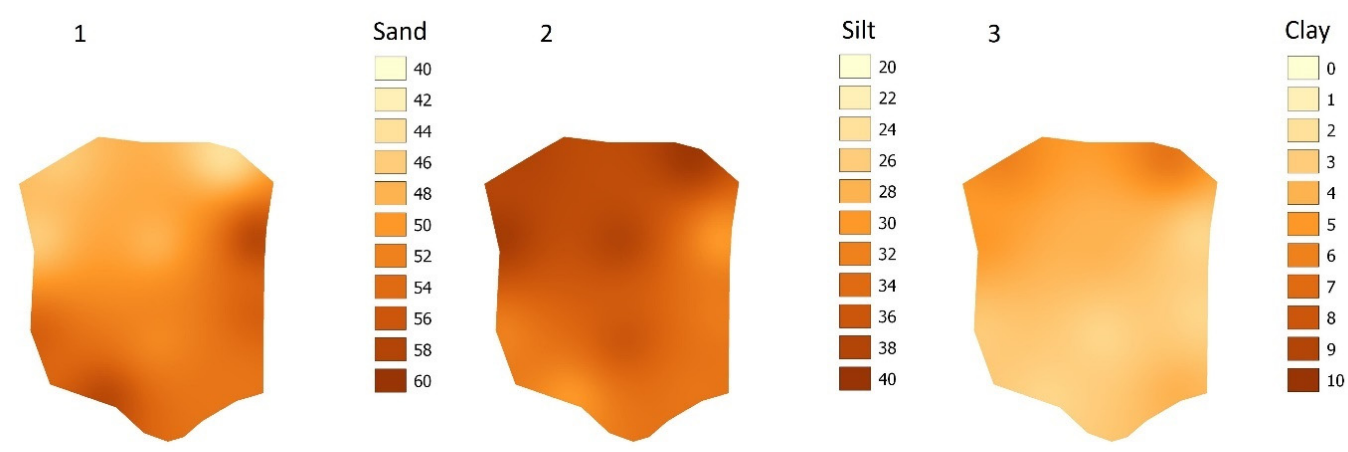

\section{$4 \mathrm{~cm}$}

Fig. 8. Spatial distribution $(\%)$ of sand $(630-2000 \mu \mathrm{m})$, silt $(630-2 \mu \mathrm{m})$, and clay $(<2 \mu \mathrm{m})$ content according to Ad-Hoc-AG Boden $(2005)$ after $2^{\text {nd }}$ order polynomial regression analysis of the sampling points along intact surfaces from Bsw horizon of a Dystric Cambisol determined by laser diffraction method (LDM) using the inverse distance weighting (IDW) algorithm in QGIS version 2.18.16 (QGIS Development Team, 2013).
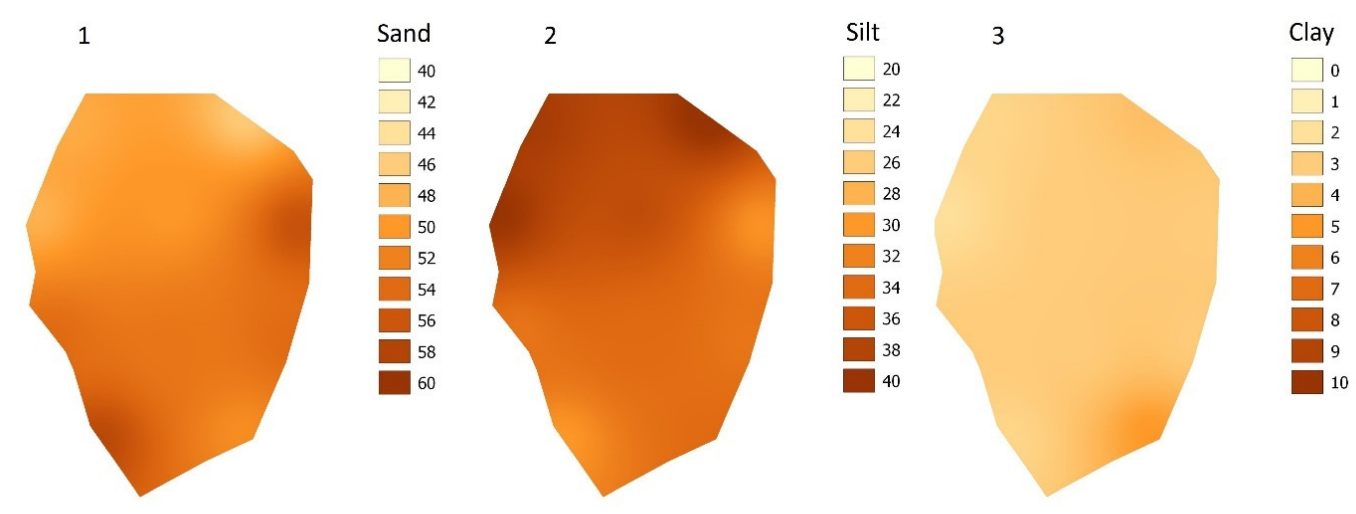

$\stackrel{4 \mathrm{~cm}}{\longleftrightarrow}$

Fig. 9. Spatial distribution (\%) of sand (630-2000 after $2^{\text {nd }}$ order polynomial regression analysis of the sampling points along intact surfaces from BwC horizon of a Dystric Cambisol determined by laser diffraction method (LDM) using the inverse distance weighting (IDW) algorithm in QGIS version 2.18.16 (QGIS Development Team, 2013).

The information about the spatial distribution of sand, silt, and clay contents enables the possibility to validate noninvasive mid-infrared spectroscopy (MIRS) (e.g., Thomas et al., 2021) and Vis-NIR spectroscopy measurements on intact aggregates (e.g., Hobley and Prater, 2019). Furthermore, the LDM-derived PSD's can be effectively used for pedotransfer functions to determine the small-scale sorption behaviour of preferential flow paths (earthworm burrows, root channels) via dye or fluorescing tracer (e.g., Beck-Broichsitter et al., 2020a), and predicting soil hydraulic functions (Bachmann et al., 2013; Fér et al., 2016). Hotspots for fertilizer and pesticide binding affinity can be identified and verified, because clay particles (mostly negatively charged) can increase the sorption of positively charged fertilizer and decrease the sorption of negatively charged pharmaceuticals (Fér et al., 2018).

\section{CONCLUSIONS}

The results of the study indicate that the laser diffraction method is hypothetically appropriate for describing spatially varying particle size distributions along intact aggregate surfaces of four silty-loamy and OC enriched horizons of a Dystric Cambisol. Thus, the derived information about the spatial dis- tribution of the particle sizes mapped via inverse distance weighting algorithm can be used for an effective validation of non-invasive mid-infrared spectroscopy and Vis-NIR spectroscopy measurements on intact aggregates. The laser diffraction method enables rapid and continuous particle size distribution measurements, and the results can be directly compared with the standardised sieve and pipette method by using regression analysis. In addition, the sample pretreatment following standardised proceedings indicates a better comparability between the particle size distributions of both methods. However, the limited evaluability and reproducibility of soil material enriched in $\mathrm{OC}$, especially the AE horizon in the current study, needs further analysis.

Acknowledgements. This study was supported by the Czech Science Foundation, project No. 20-00788S.

\section{REFERENCES}

Ad-hoc-AG Boden, 2005. Bodenkundliche Kartieranleitung. $5^{\text {th }}$ ed. Bundesanstalt für Geowissenschaften und Rohstoffe und Niedersächsisches Landesamt für Bodenforschung, Hannover. 
Bachmann, J., Goebel, M.-O., Woche, S.K., 2013. Smallscale contact angle mapping on undisturbed soil surfaces. J. Hydrol. Hydromech., 611, 3-8. https://doi.org/10.2478/johh2013-0002

Beck-Broichsitter, S., Gerriets, M.R., Gerke, H.H., Sobotkova, M., Dusek, J., Dohrmann, R., Horn, R., 2020a. Brilliant Blue sorption characteristics of clay-organic aggregate coatings from Bt-horizon. Soil Till. Res., 201, 104635. https://doi.org/10.1016/j.still.2020.104635

Beck-Broichsitter, S., Gerriets, M.R., Puppe, D., Leue, M., Sobotkova, M., Dusek, J., Gerke, H.H., 2020b. Laser-based 3D microscopic gauging of soil aggregate coating thickness and volume. Soil Till. Res., 204, 104715. https://doi.org/10.1016/j.still.2020.104715

Beck-Broichsitter, S., Ruth, S., Schröder, R., Fleige, H., Gerke, H.H., Horn, R., 2020c. Simultaneous determination of wettability and shrinkage in an organic residue amended loamy topsoil. J. Hydrol. Hydromech., 68, 2, 111-118. https://doi.org/10.2478/johh-2020-0007

Bieganowski, A., Ryżak, M., Sochan, A., Barna, G., Hernádi, H., Beczek, M., Polakowski, C., Makó, A., 2018. Chapter Five - Laser diffractometry in the measurements of soil and sediment particle size distribution. Advances in Agronomy 151, 215-279.

Blume, H.-P., Stahr, K., Leinweber, P., 2011. Bodenkundliches Praktikum - Eine Einführung in pedologisches Arbeiten für Ökologen, Land- und Forstwirte, Geo- und Umweltwissenschaftler. Spektrum Akademischer Verlag, Heidelberg.

de Oliveira, J.S., Inda, A.V., Barrón, V., Torrent, J., Tiecher, T., de Oliveira Camargo, F.A., 2020. Soil properties governing phosphorus adsorption in soils of Southern Brazil. Geoderma Regional, 22, e00318 https://doi.org/10.1016/ j.geodrs.2020.e00318

Dohnal, M., Vogel, T., Sanda, M., Jelinkova, V., 2012. Uncertainty analysis of a dual-continuum model used to simulate subsurface hillslope runoff involving oxygen-18 as natural tracer. J. Hydrol. Hydromech., 60, 3, 194-205. https://doi.org/10.2478/v10098-012-0017-0

Dusek, J., Vogel, T., 2019. Modeling travel time distributions of preferential subsurface runoff, deep percolation and transpiration at a montane forest hillslope site. Water, 11, 2396. https://doi.org/10.3390/w11112396

Fér, M., Leue, M., Kodešová, R., Gerke, H.H., Ellerbrock, R.H., 2016. Droplet infiltration dynamics and soil wettability related to soil organic matter of soil aggregate coatings and interiors. J. Hydrol. Hydromech., 64, 111-120. https://doi.org/10.1515/johh-2016-0021

Fér, M., Kodešová, R., Golovko, O., Schmidtová, Z., Klement, A., Nikodem, A., Kočárek, M., Grabic, R., 2018. Sorption of atenolol, sulfamethoxazole, and carbamazepine onto soil aggregates from the illuvial horizon of the Haplic Luvisol on loess. Soil Water Res., 13, 177-183. https://doi.org/10.17221/82/2018-SWR

Goossens, D., 2008. Techniques to measure grain-size distributions of loamy sediments: A comparative study of ten instruments for wet analysis. Sedimentology, 55, 65-96. https://doi.org/10.1111/j.1365-3091.2007.00893.x

Grehan, G., Maheu, B., Gouesbet, G., 1986. Scattering of laser beams by Mie scatter centers: numerical results using a localized approximation. Appl. Opt., 25, 19, 3539-3548. https://doi.org/10.1364/AO.25.003539

Hasler, M., Horton, L.A., 2008. Multiple contrast tests in the presence of heteroscedasticity. Biometrical J., 50, 793-800. https://doi.org/10.1002/bimj.200710466

Hobley, E.U., Prater, I., 2019. Estimating soil texture from
vis-NIR spectra. Eur. J. Soil Sci., 70, 1, 83-95. https://doi.org/10.1111/ejss.12733

Igaz, D., Aydin, E., Šinkovičová, M., Šimanský, V., Tall, A., Horák, J., 2020. Laser diffraction as an innovative alternative to standard pipette method for determination of soil texture classes in Central Europe. Water, 12, 1232. https://doi.org/10.3390/w12051232

ISO 1332:2020-01. Particle Size Analysis - Laser Diffraction Methods. International Organization for Standardization, Geneva, Switzerland.

ISO 11277:2020. Soil quality - Determination of particle size distribution in mineral soil material - Method by sieving and sedimentation. International Organization for Standardization, Geneva, Switzerland.

IUSS Working Group WRB, 2015. World Reference Base for Soil Resources 2014, update 2015. International soil classification system for naming soils and creating legends for soil maps. World Soil Resources Reports No. 106. FAO, Rome.

Jensen, J.L., Schjønning, P., Watts, C.W., Christensen, B.T., Munkholm, L.J., 2017. Soil texture analysis revisited: Removal of organic matter matters more than ever. PLoS ONE, 12, 5, e0178039. https://doi.org/10.1371/journal.pone.0178039

Koza, M., Schmidt, G., Bondarovich, A., Akshalov, K., Conrad, C., Pöhlitz, J., 2021. Consequences of chemical pretreatments in particle size analysis for modelling wind erosion. Geoderma, 396, 115073. https://doi.org/10.1016/j.geoderma.2021.115073

Kubínová, R., Neumann, M., Kavka, P., 2021. Aggregate and particle size distribution of the soil sediment eroded on steep artificial slopes. Appl. Sci., 11, 4427. https://doi.org/10.3390/app11104427

Leue, M., Wohld, A., Gerke, H.H., 2018. Two-dimensional distribution of soil organic carbon at intact macropore surfaces in BT-horizons. Soil Till. Res., 176, 1-9. https://doi.org/10.1016/j.still.2017.10.002

Leue, M., Beck-Broichsitter, S., Felde, V.J.M.N.L., Gerke, H.H., 2019. Determining mm-scale maps of cation exchange capacity at macropore surfaces in Bt-horizons. Vadose Zone J., 16, 9. https://doi.org/10.2136/vzj2018.08.0162

Leue, M., Uteau, D., Peth, S., Beck-Broichsitter, S., Gerke, H.H., 2020. Volume-related quantification of organic carbon content and cation exchange capacity of macropore surfaces in Bt horizons. Vadose Zone J., 19, e20069. https://doi.org/10.1002/vzj2.20069

Li, J, Heap, A.D., 2011. A review of comparative studies of spatial interpolation methods in environmental sciences: performance and impact factors. Ecol. Inform., 6, 228-241. https://doi.org/ 10.1016/j.ecoinf.2010.12.003

Makó, A., Szabó, B., Rajkai, K., Szabó, J., Bakacsi, Z., Labancz, V., Hernádi, H., Barna, G., 2019. Evaluation of soil texture determination using soil fraction data resulting from laser diffraction method. Int. Agrophys., 33, 4, 445454. https://doi.org/10.31545/intagr/113347

Mastersizer 3000 User Guide, 2020. Malvern Panalytical Ltd, Malvern, UK.

McNeill, S.J., Liburne, L.R., Carrick, S., Webb, T.H., Cuthill, T., 2018. Pedotransfer functions for the soil water characteristics of New Zealand soils using S-map information. Geoderma, 326, 96-110. https://doi.org/10.1016/j.geoderma.2018.04.011

Mehra, O.P., Jackson, M.L., 1960. Iron oxide removal from soils and clays by a dithionite-citrate system buffered with sodium bicarbonate. Clay Clay Miner., 7, 317-327. https://doi.org/10.1346/CCMN.1958.0070122

Merkus, H.G., 2009. Particle Size Measurements: Fundamentals, Practice, Quality. Springer, Dordrecht, the Netherlands. Mikutta, R., Kleber, M., Torn, M.S., Jahn, R., 2006. Stabiliza- 
tion of soil organic matter: association with minerals or chemical recalcitrance? Biogeochemistry, 77, 25-56. https://doi.org/10.1007/s10533-005-0712-6

Polakowski, C., Ryzak, M., Sochan, A., Beczek, M., Mazur, R., Bieganowski, A., 2021. Particle size distribution of various soil materials measured by laser diffraction - the problem of reproducibility. Minerals, 11, 465. https://doi.org/10.3390/min11050465

QGIS Development Team, 2013. Geographic Information System. Open Source Geospatial Foundation. http://qgis.org.

R Development Core Team, 2021. R: A language and environment for statistical computing. R Foundation for Statistical Computing, Vienna, Austria.

Sanda, M., Cislerova, M., 2009. Transforming hydrographs in the hillslope subsurface. J. Hydrol. Hydromech., 57, 264275. https://doi.org/10.2478/v10098-009-0023-z

Sanda, M., Vitvar, T., Kulasova, A., Jankovec, J., Cislerova, M., 2014. Run-off formation in a humid, temperate headwater catchment using a combined hydrological, hydrochemical and isotopic approach (Jizera Mountains, Czech Republic). Hydrol. Process., 28, 3217-3229. https://doi.org/10.1002/hyp.9847

Soil Survey Staff, 1999. Soil Taxonomy: A basic system of soil classification for making and interpreting soil surveys. USDA, Washington, DC, 869 p.
Stokes, G.G., 1851. On the effect of the internal friction of fluids on the motion of pendulums, 9. Pitt Press Cambridge.

Thomas, C.L., Hernandez-Allica, J., Dunham, S.J., McGrath, S.P., Haefele, S.M., 2021. A comparison of soil texture measurements using mid-infrared spectroscopy (MIRS) and laser diffraction analysis (LDA) in diverse soils. Sci. Rep., 11, 16. https://doi.org/10.1038/s41598-020-79618-y

Vdović, N., Obhođaš, J., Pikelj, K., 2010. Revisiting the particle-size distribution of soils: comparison of different methods and sample pre-treatments. Eur. J. Soil Sci., 61, 854864. https://doi.org/10.1111/j.1365-2389.2010.01298.x

Yang, Y., Wang, L., Wendroth, O., Liu, B., Cheng, C., Huang, T., Shi, Y., 2019. Is the Laser diffraction method reliable for soil particle size distribution analysis? Soil Sci. Soc. Am. J., 83, 2. https://doi.org/10.2136/sssaj2018.07.0252

Zarco-Perello, S., Simões, N., 2017. Ordinary kriging vs inverse distance weighting: Spatial interpolation of the sessile community of Madagascar Reef, Gulf of Mexico. Peer J., 5, e4078. https://doi.org/10.7717/peerj.4078

Zimmermann, I., Horn, R., 2020. Impact of sample pretreatment on the result of texture analysis in different soils. Geoderma, 371, 114379. https://doi.org/10.1016/j.geoderma.2020.114379

Received 29 June 2021 Accepted 13 December 2021 